around the world. Most of these individuals will seek education as the conduit back to normalcy, some will seek higher education, and a small number will go on to make remarkable contributions to human development, much as other notable refugees have historically done. We cannot turn our back on their potential and allow an entire generation or more to be lost.

Researchers and practitioners alike may look to the contemporary German case to learn from both best practices and common challenges. In this collaborative learning process, the larger community of educators including the DAAD in Germany, the Institute of International Education in the United States and the World University Service of Canada, among others, will come a step closer to supporting not only the I percent of refugees worldwide who access higher education, but also the 99 percent who remain excluded.

DOI: http://dx.doi.org/Io.6oI7/ihe.20I8.95.10687

\section{African Academic Diaspora: Training and Research}

\section{Claudia Frittelli}

Claudia Frittelli is program officer, International Program, Carnegie Corporation of New York, US. E-mail: cf@carnegie.org.

$\mathrm{T}$ ertiary education enrollment in sub-Saharan Africa nearly doubled from approximately 4.5 million in 2000 to 8.8 million in 2016 (UNESCO UIS). To meet the needs of new and expanding universities, several African governments, including Kenya and South Africa, have set targets or identified a need to increase the number of doctoral graduates by the thousands over the next decade in order to improve the quality and size of academic staff. A 2015 UNESCO Science Report advises that with expanded enrollment coming primarily from newly industrializing countries, the future of higher education is dependent on university networks that enable universities to share their faculty, courses, and research projects. University exchanges with academic diaspora are an effective entry point to do so. According to an April 2018 Pew Research Center report, subSaharan African immigrants in the United States are more highly educated than their counterparts in Europe, and 69 percent of those aged 25 or older in 2015 said that they had at least some tertiary education experience. A number of African universities and institutions have developed inno- vative models to incorporate diaspora linkages in developing the next generation of academics.

\section{Diaspora Engagement in Research Networks}

The African Institute of Mathematical Sciences (AIMS) Research Chair program goals are to enable exceptional African graduates with more than two years of postdoctoral research experience who are based outside Africa to firmly establish themselves in Africa while continuing international-class research. AIMS has recruited eight African diaspora research chairs based in Europe and North America across its six centers in Cameroon, Ghana, Rwanda, Senegal, South Africa, and Tanzania for four- to five-year terms, and plans to recruit an additional five in 2018. Founded in 2003, and headquartered in Kigali, Rwanda, AIMS recruits talented university graduates and provides them with the cutting-edge training in mathematics that they need to enter technical professions or pursue graduate studies in technical fields. Research Chairs support scientific development in Africa through research, teaching, and creating research groups of excellence with a focus on applied mathematical science and international and inter-African collaboration. Chairs' activities include master's, doctoral, and postdoctoral supervision; scientific event organization; coordinating visiting lecturers; and research mobilization and partnership building. AIMS has partnerships with over 200 universities, 300 researchers, and 500 lecturers worldwide, and produces approximately 70 peer-reviewed research publications and 300 dissertations per year. Exposing students to new mathematical science domains with top scientists from around the world, AIMS has since its inception graduated over 1500 alumni from 42 African countries, with graduates including over 30 percent of women. The majority of alumni are pursuing doctoral degrees or working in Africa.

\section{Institutional Deployment of Academic Diaspora}

The Institute of Post-School Studies of the University of the Western Cape (UWC) in Cape Town, South Africa, and Eduardo Mondlane University in Maputo, Mozambique, have deployed diaspora academics to design a new doctoral program in comparative higher education, science, and innovation studies, aiming to produce researchers and practitioners for Africa's expanding higher education sector. Together with UWC faculty, diaspora visiting lecturers from leading institutions worldwide have contributed to curricula design, seminars and public lectures, short courses on research methodology, and doctoral cosupervision. To meet the increased demand for methodological training, the University of Ghana's (UG) Pan-African Doctoral Academy (PADA) has engaged 20 academics from the diaspora 
who work alongside UG faculty. PADA supports doctoral students and early career faculty with training, mentoring, career guidance, and scholarship, with an overarching goal to increase the quality of $\mathrm{PhD}$ education in West Africa. PADA has trained 400 African doctoral students since its inception in 20I4. Valuing the approach, vice-chancellors at Kwara State University in Nigeria and the University of Johannesburg in South Africa have replicated versions of the PADA diaspora model. Further, the Health Sciences Research Office of the University of the Witwatersrand (Wits) in Johannesburg, South Africa, targets alumni in scarce skills domains for reciprocal research collaboration, lecturing, postgraduate supervision, and sharing of laboratories. Visits by 24 Wits diaspora alumni fellows over four years have led to ongoing collaboration with six leading universities, I4 joint publications, five joint grants, postgraduate supervision, and development of a health application database consortium.

\section{Research Chairs support scientific de- velopment in Africa through research, teaching, and creating research groups of excellence.}

\section{Are Academic Diaspora Lin kages Sustainable?}

External funders have strengthened several of these programs, but are the linkages sustainable? A survey conducted by the Carnegie African Diaspora Fellowship Programwhich has supported 335 academic diaspora fellowship visits to African universities since 2013-found that of 103 North American diaspora fellows who were funded for up to three-month visits at African universities, 98 percent reported having visited Africa in recent years before the fellowship. This survey saw a 77 percent response rate. Of the 98 percent of respondents who had recently visited Africa, 66 percent visited for personal reasons and 60 percent visited to conduct research. Thirty-three percent had previously visited their host institutions and 35 percent had worked virtually with host collaborators prior to the fellowship.

According to a six-month postfellowship survey, 78 percent of program participants reported that they continue to stay engaged in academic activities with their host collaborator. A one-year alumni survey of 58 fellows (a 53 percent survey response rate) showed that 84 percent of fellows reported that they communicate at least once or twice a month with scholars and administrators from their host institution, and $4 \mathrm{I}$ percent ( 24 fellows) reported that they visited the host institution following the initial project visit for professional reasons. Progress in no- or low-cost technology and connectivity is enabling ongoing collaboration.

\section{Intellectual Remittances Contribute to Educational TARGETS}

African governments have mostly been interested in financial remittances from the diaspora, but intellectual remittances provide a means to meet their educational targets. In his April 20I8 inaugural speech, newly appointed prime minister Abiy Ahmed Ali of Ethiopia stated that maximum effort would be made to ensure that graduates from higher education institutions and technical and vocational colleges "harvest knowledge that is comparable to their endowment of abilities." He subsequently called on the diaspora to contribute, saying that the government would continue with unreserved efforts to facilitate their active participation in the country's affairs and its transformation in any way that they could. In a March 20I8 presidential panel at the Next Einstein Forum in Kigali, Rwanda, President Paul Kagame claimed that 80-85 percent of Rwandans who had studied abroad had come back to Rwanda due to a conducive environment.

The future of higher education is increasingly transnational. According to UNESCO, four million students (2 percent of all university students) are registered abroad, and this figure is expected to double by 2025. In this context, creating connections between African universities and academic diaspora communities interested in sharing intellectual capital and resources is a catalyst for scholarly exchange, broader academic communities, and innovation in higher education. Early findings of academic diaspora linkage programs indicate substantial leveraging of additional funds, expertise, technology, and goodwill, which is benefiting both home and host institutions.

DOI: http://dx.doi.org/ıo.60I7/ihe.20I8.95.10687

\section{Repositioning UK Partner- ships Post-Brexit}

\section{LUDOVIC HIGHMAN}

Ludovic Highman is senior research associate at the Centre for Global Higher Education, Institute of Education, University College London, UK.E-mail: I.highman@ucl.ac.uk.

$F$ llowing the Brexit referendum of June 2016, the implications for higher education and research of the United Kingdom leaving the European Union were not 